\title{
Şişen Zeminlerdeki Kireç Kolonu Uygulamalarında İyon Göçü Mekanizması
} Ion Migration Mechanism in Lime Column Applications in Swelling Soils

\author{
Derya TOKSÖZ HOZATLIOĞLU ${ }^{*} \mathbb{D}$, Işsk YILMAZ ${ }^{1} \mathbb{D}$ \\ Sivas Cumhuriyet Üniversitesi, Mühendislik Fakültesi, Jeoloji Mühendisliği Bölümü, Sivas, 58140
}

Geliş (Received): 02 Ekim (October) 2021 / Düzeltme (Revised): 20 Ekim (October) 2021 / Kabul (Accepted): 01 Kasım (November) 2021

ÖZ

Şişen zeminlerin kireç kolonu tekniği ile iyileştirilmesi çok uzun yıllardır araştırılmakta olup, literatürde bu konu ile ilgili pek çok çalışma mevcuttur. Bu çalışmalardaki yaygın görüş kireç kolonu tekniğinin iyileştirme mekanizmasının kireç içerisindeki $\mathrm{Ca}^{+2}$ ve $\mathrm{OH}^{-}$iyonlarının kolonu çevreleyen zemine göç etmesi sonucu oluşan fiziko-kimyasal reaksiyonlara dayandığıdır. Buna rağmen çok az sayıda çalışmada iyileştirmenin temelini oluşturan iyon göçünden ve iyon göçünü etkileyen faktörlerden bahsedilmiştir. Bu çalışma derleme türü bir çalışma olup çalışmanın amacı kireç kolonu uygulamalarında iyon göçü mekanizmasının daha iyi anlaşılmasını sağlamaktır. Çalı̧̧ma kapsamında öncelikle iyonların genel olarak zemin ortamındaki hareketinden bahsedilmiştir. Ardından zeminlerin kireç kolonu tekniği ile iyileştirilmesi sırasında oluşan iyon göçü mekanizması ve son olarak iyon göçünü etkileyen faktörler bu konuda yapılan çalışmalara değinilerek açıklanmıştır. Çalışma sonucunda literatürde iyon göçünü açıklayan tek ve kesin bir mekanizmanın bulunmadığı görülmüştür. Ancak yapılan çalışmalardan yola çıkılarak kireç içerisindeki iyonların zemin içerisine olan göçünün genel olarak iyon difüzyonu ve su akışına bağlı kütle iletiminin bir fonksiyonu olduğu söylenebilir.

Anahtar Kelimeler: Şişen Zeminler, Kireç Kolonu, İyileştirme, İyon Göçü

\begin{abstract}
Stabilisation of swelling soils by using lime column technique has been investigated for many years and there have been numerous studies on this topic in the literature. The common view in these studies is that stabilisation mechanism of lime column technique is based on physico-chemical reactions occurred as a result of migration of $\mathrm{Ca}^{2+}$ and $\mathrm{OH}^{-}$ions from lime column to the surrounding soil. In spite of this, ion migration which is the basis of stabilisation, and the factors affecting ion migration have been mentioned in very few studies. This study is a review type study and the purpose of the study is to provide a better understanding of the mechanism of ion migration in lime column applications. In the scope of the study, firstly, movement of ions in soil medium in general is explained. Afterwards, ion migration mechanism that occurs during the stabilisation of swelling soils with lime column technique, and finally the factors affecting ion migration mechanism are explained by referring to the studies on this topic. In the result of the study, it was seen that in the literature there is no a single and precise mechanism that explain ion migration. However, it can be said that the migration of ions into the soil is a function of ion diffusion and mass transport depending on water flow.
\end{abstract}

Keywords: Swelling Soils, Lime Column, Stabilisation, Ion Migration 
Toksöz Hozatlığlu, Yılmaz

\section{GIRIŞ}

İnsanoğlu varoluşundan beri barınma ve savunma gibi ihtiyaçları için gerekli olan yapıları zemin üzerinde inşa etmekte veya zemini çeşitli toprak yapıların (toprak dolgu baraj1, yol temeli gibi) oluşturulmasında kullanmaktadır. İnşa edilecek yapıların güvenlive ekonomik olabilmesi için kullanılacak zeminin özeliklerinin jeolojik ve jeoteknik yönden incelenmesi büyük önem arz etmektedir. Bazı zemin koşulları sorunlu olup, tasarımdan önce ek iyileştirmeler istemektedir. Bunlara sorunlu zeminler denilmektedir. En yaygın olarak karşılaşılan sorunlu zeminler ise şişen zeminlerdir.

Şişen zeminler 1slanma veya kuruma sonucunda hacim değişikliğine uğrayan killi zeminlerdir. Zemin şişmelerinin neden olduğu hasarlar özellikle hafif yapılar (tek katlı binalar), park alanları, yollar ve tretuvarlar, havaalanları, altyapı tesisleri, sulama kanalları, bahçe duvarları ve tüneller gibi yapılarda daha fazla oluşmaktadır. Zemin yüzeyinde oluşacak kabarma ve büzülmenin miktarı çoğunlukla bir yapının altındaki alan içerisinde dahi farklılıklar gösterebilir. Bunun sonucu olarak, temel sisteminin farklı noktalarında değiş̧ik miktarlarda hareketler oluşabilir.

Şişen zeminlerin neden olduğu problemlerin büyük bir kısmından sorunun inşaat öncesi çalışmalarda teşhis edilmesi ve uygun koruyucu önlemlerin alınması ile kaçınılabilmektedir. Şişen zeminlerden kaynaklanan problemlerden kaçınmak için en sık başvurulan yöntem zeminin yerinde yapılan işlemlerle iyileştirilmesidir. Zemin iyileştirmesi zeminlerin istenmeyen özelliklerininyapılması planlanan birmühendislik uygulamasına yönelik olarak çeşitli fiziksel ve kimyasal yöntemler kullanılarak istenilen yönde değiştirilmesi olarak tanımlanabilir. Şişen zeminler için en yaygın olarak kullanılan iyileştirme yöntemi çeşitli katkı maddeleri ile yapılan kimyasal iyileştirmedir. Kimyasal iyileştirme kil ile katkı maddeleri arasında gerçekleşen fizikokimyasal reaksiyonlara dayanır. Literatürde en yaygın olarak kullanılan katk1 maddesi ise kireçtir (Snethen, 1979).

Kireç ile iyileştirilmiş bir zemin elde etmek için kullanılan başlıca iki metot vardır; bunlar yüzeysel karıştırma ve kolon teknikleridir. Yüzeysel karıştırma tekniğinde zemin özel bir araçla gevşetilir, üzerine belirli miktarda kireç serilir ve killi malzeme ile kireç uygun su içeriğinde karıştırılır ve son olarak sıkıştırılır. Bu yöntemde iyileştirme fazla derinlere inilmeden yapılır. Kolon tekniğinde ise zemin içerisinde belirli aralıklarla gerekli derinlik ve çaplarda delikler açılır ve bu delikler kireç ile doldurulur. Kolonlar oluşturulduktan sonra zaman içerisinde kireç içerisindeki iyonlar kolonu çevreleyen zemine göç etmeye başlar. Bunun sonucu olarak kirecin içerdiği pozitif iki değerlikli iyonlar ile negatif yüklü kil mineralleri arasında fizikokimyasal reaksiyonlar gerçekleşir.

Kireç kolonu uygulamalarında kirecin içerdiği iyonların zemine olan göçü iyileşmenin oluşabilmesi için en önemli süreçtir (Rogers ve Glendinning, 1994). Dolayısıyla, iyon göçü mekanizmasının anlaşılması, iyon göçünü etkileyen faktörlerin bilinmesi ve uygulamaların bu faktörler dikkate alınarak yapılması iyileştirme performansı açısından önemlidir. Literatürde kireç kolonu tekniği ile ilgili çok sayıda çalışma olmasına rağmen bunların çok az bir kısmında iyon göçü mekanizmasından bahsedilmiştir. Özellikle ulusal literatürde iyon göçü mekanizmasının açıklandığı bir çalışmaya rastlanmamıştır. Mevcut çalışmalarda çoğunlukla bir kireç kolonu oluşturulur ve kolondan itibaren belirli mesafelerde alınan örnekler üzerinde serbest basınç ya da şişme deneyleri yapılarak 
iyileştirmenin ne boyutta ve hangi mesafelerde olduğuna bakılır. Ancak iyileştirmenin temelini oluşturan iyon göçünden çok az söz edilir. $\mathrm{Bu}$ çalışma derleme türü bir çalışma olup, çalışmanın amacı şişen zeminlerin kireç kolonu tekniği ile iyileştirilmesi sırasında oluşan iyon göçü mekanizmasının daha iyi anlaşılmasını sağlamaktır. Çalışma kapsamında öncelikle genel olarak iyonların zemin ortamındaki hareketinden ve bu konu ile ilgili olarak yapılan önceki çalışmalardan bahsedilmiştir. Ardından, zeminlerin kireç kolonu tekniği ile stabilizasyonu sırasındaki iyon göçü ve son olarak iyon göçünü etkileyen faktörler bu konuda yapılan çalışmalara değinilerek açıklanmıştır.

\section{KILLLI ZEMINLERDE IYYON GÖÇÜ}

İyon göçü kimyasal zemin iyileştirme çalışmalarının yanı sıra bazı ziraat ve çevre mühendisliği uygulamalarının da temelini oluşturmaktadır. Ziraat mühendisliğinde iyon göçü toprak-su sistemi için oldukça önemlidir. Toprağa eklenen gübreler toprak içerisinde çözünür ve bitki besin elementleri iyon göçü mekanizmasıyla bitki kök bölgesine taşınırlar (Öztaş, 1997). Çevre mühendisliğinde ise katı atık depolama sahalarındaki kirleticilerin geçişinin incelenmesinde iyon göçü mekanizmasının anlaşılması önemlidir. Kirleticilerin geçirimsizlik tabakasından doğal zemine geçişi iyon göçü mekanizması tarafindan kontrol edilmektedir (Adar, 2013). Dolayısıyla killi zeminlerde oluşan iyon göçü ile ilgili bilgilere değişik disiplinlerde rastlanabilmektedir. Aşağıda bu çalışmalardan derlenen bilgiler sunulmuştur.

Killi zeminlerde iyon göçünü sağlayan başlıca iki mekanizma vardır. Bunlar adveksiyon ve difüzyondur. Advektif geçiş iyon göçünün kil boyunca su akımıyla gerçekleşmesi olarak tanımlanabilir (Edil, 2003). Difüzif geçişte ise iyonlar yüksek konsantrasyonda bulundukları bir bölgeden düşük konsantrasyonda bulundukları bölgeye hareket ederler. Rogers ve Glendinning (1996), difüzyon sürecinin iyon değişimiyle kontrol edildiğini belirtmişlerdir. Yüksek plastisiteli zeminlerde iyonların hareketinde difüzyon mekanizması etkindir. Adveksiyon mekanizması ise zeminin geçirimliliği oranında etkili olabilmektedir. Dolayısıyla düşük plastisiteli ya da önemli oranda iri bileşen içeren zeminlerde iyonların iletiminde adveksiyon mekanizması daha etkilidir denilebilir (Mitchell ve Soga, 2005).

Elektriksel ve magnetik alanlar gibi değişik tipteki kuvvetlerin varlığı da iyonların hareketini etkileyebilir. Her iyonun bir difüzyon katsayısı vardır, ancak iyonlar iyon çifti olarak bulunduklarında kendi difüzyon hılarında hareket etmezler. Bunun nedeni elektriksel kuvvetlerdir. Elektriksel kuvvetler hızlı iyonu yavaşlatmaya yavaş iyonu ise hızlandırmaya eğilimlidirler. Böylece iyon çifti iyon hızlarının ağırlıklı ortalamasında hareket eder. Ancak eğer iyonlar ve kil arasında herhangi bir reaksiyon söz konusu olursa, örneğin iyonlardan birinin kilin yapısındaki herhangi bir iyonla yer değiştirmesi söz konusuysa, bu durumda difüzyon sadece iyon çiftine değil, ayrıca kilin ve kildeki değişebilir iyonun türüne de bağlıdır (Jungnickel vd., 2004).

Zeminlerdeki iyon göçü sıvı çözeltilerde oluşan iyon göçünden daha komplekstir. Mitchell (2005) bunun başlıca nedenlerini şöyle açıklamıştır:

1. Gözenekli ortamdaki partiküller nedeniyle difüzyon yolları lineer değildir.

2. Kil partiküllerinin elektriksel alanı difüze olan iyonların göç yollarını etkileyebilir.

3. Bazı iyonların gecikmesinin nedeni kil mineralleri üzerine adsorpsiyonu ve iyon değişimidir. 
Toksöz Hozatlığlu, Yılmaz

Bir akışkan içerisindeki toplam konsantrasyon sabit ise moleküler difüzyon Fick'in birinci kanununa göre aşağıdaki gibi yazılır (Öztaş, 1997):

$\mathrm{F}=\mathrm{dQc} / \mathrm{dt}=-\mathrm{DA}(\mathrm{dC} / \mathrm{dx})$

Burada;

Qc: difüze olan iyon miktarı, $\mathrm{g} \mathrm{mol}^{-1}$

$\mathrm{t}:$ zaman, $\mathrm{s}$

$\mathrm{D}$ : difüzyon katsay1s1, $\mathrm{cm}^{2} \mathrm{~s}^{-1}$

A : kesit alan1, $\mathrm{cm}^{2}$

$\mathrm{C}$ : konsantrasyon, $\mathrm{g} \mathrm{cm}^{-3}$

$\mathrm{x}$ : difüze olan iyonun hareket yönündeki mesafe, $\mathrm{cm}$.

Fick' in kanunu sıv1 veya gaz gibi uniform ortamlardaki difüzyonu tanımlamak amacıyla üretilmiştir. Zemin ise kompleks ve değişken bir ortamdır. Zemin içerisindeki iyonların difüzyonunu açıklamak için zeminin farklı fiziksel, kimyasal ve geometrik karakteristiklerini dikkate almak ve onu düzensiz paketlenmiş, elektrik yüklü, kompleks gözenekli bir malzeme olarak düşünmek gerekmektedir (Öztaş, 1997). Dolayısıyla zemindeki iyonların difüzyon katsayılarında değişikliklere neden olan etkilerin tanımlanması ve difüzyon eşitliğine eklenmesi gereklidir. Bu etkilerden bazıları; akış yolunun pürüzlülüğü, suyun nispi akışkanlığı, elektrostatik sınırlama ve kesit alanının azalması olarak sayılabilir. Zemindeki difüzyonu tanımlamak için bu faktörlerden ilk üçü bir araya getirilerek "azaltıc1 faktör" (f) ismi altında difüzyon eşitliğine eklenmektedir. Azaltıcı faktör, daima 1 'den küçük bir değer almakta olup zemindeki nem içeriği, agregatlaşma ve sıkışma tarafindan etkilenmektedir (Öztaş, 1997).

$\mathrm{f}=(\mathrm{L} / \mathrm{Le})^{2} \mathrm{rf}$
Burada;

Le: iyonların bir noktadan diğer bir noktaya giderken izlediği yol

L: iki nokta arasındaki izafi mesafe

rf: suyun nispi akışkanlığından kaynaklanan değişim

Zeminlerde oluşan iyon göçü sadece difüzyon (kimyasal gradyan) tarafindan kontrol edilmemektedir. Ortamdaki elektriksel, hidrolik ya da termal gradyanların varlığı da iyon göçünü etkilemektedir. Bir ortamda herhangi bir gradyan yüzünden oluşan iyon göçü hem itici kuvvetin (ortam boyunca olan gradyanın magnitüdü) hem de akış katsayısının (ortamın akışkana karşı olan direncinin tersi) bir fonksiyonudur (Barker vd., 2007). 4 ana akış türü Barker vd. (2007) tarafından aşağıdaki şekilde açıklanmıştır.

Kimyasal aklş: Diğer bir ismi difüzyondur. Kimyasal türlerin konsantrasyondaki gradyan yüzünden iletimidir. Zemin boyunca oluşan difüzyon, akımın azalan kesit alanı, akım yolunun eğrilik katsayısının artması ve farklı kimyasal türler ve boşluk suyu arasındaki etkileşim yüzünden azalır.

Elektriksel akış: Bir ortam boyunca uygulanan elektriksel potansiyel yüzünden oluşan iyon iletimidir. Ohm kanunu ile tanımlanır. $\mathrm{Bu}$ kanuna göre bir ortamda elektriksel alan oluştuğunda elektronlar hızlanır ve kinetik enerji kazanır. Bu elektronlar atomlarla çarpışır ve kinetik enerjiyi transfer ederler. Elektriksel iletkenlik yoğunluktan ve ortam içindeki yük taşıyıcılarının serbestliğinden etkilenir. Zemin içerisindeki elektriksel iletkenlik su içeriği, iyonik dayanım, boşluk sıvısı içerisindeki konsantrasyon, zeta potansiyeli ve zemin sıcaklığının bir fonksiyonudur. 
Hidrolik akış: Hidrolik gradyan yüzünden oluşan siv1 iletimidir. Darcy kanunu ile tanımlanır. Bu kanuna göre sıvıların ve gazların akmaya olan dayanımı viskoziteye bağlıdır. Zemin içindeki sıvı akışı doygunluk derecesinin, partikül boyutunun, paketlenme düzeninin ve sıcaklığın bir fonksiyonudur.

Termal akış: Sıcaklık gradyanı yüzünden iç enerjinin iletkenlik, konveksiyon ve 1şınım ile iletilmesidir (Fourier kanunu). İç enerji atomların denge pozisyonları civarında titreyerek sahip oldukları enerjidir. Zemin içindeki termal akış doygunluk derecesinin bir fonksiyonudur.

Zemin boyunca iyonların akış katsayısını ölçmek zeminin heterojen olması ve bağlaşık akışların oluşmasından dolayı karışıktır. Bir zemin sistemi boyunca pek çok akış tipinin oluşması karışık analiz metotlarını gerektirir. Barker vd. (2007) çalışmasında bu karışık analiz metotlarından bazılarını açıklamıştır. Mevcut çalışmada bu karışık analiz metotlarına değinilmemiş olup kireç kolonu uygulamalarında oluşan iyon göçü mekanizması açıklanmıştır.

\section{KİREÇ KOLONU UYGULAMALARINDA İYON GÖÇÜ MEKANIZMASI}

Kireç kolonu tekniğinin iyileştirme mekanizması kireç içerisindeki iyonların kolonu çevreleyen zemine zamanla göçü sonucu kil ile kireç arasında oluşan fizikokimyasal reaksiyonlara dayanır. $\mathrm{Bu}$ reaksiyonlar kirecin içerdiği pozitif iki değerlikli iyonlar ve negatif olarak yüklü kil mineralleri arasında meydana gelir ve iyileştirme mekanizmasının temelini oluşturur. İyon göçünün oluşabilmesi için zeminin yeterli nem içeriğine sahip olması gerekir. Bu yüzden Ruenkrairergsa ve Pimsarn (1982), göçün gerçekleşebilmesi için kireç kolonlarının yağmurlu mevsimlerden önce inşa edilmesi gerektiğini önermişlerdir. Kireç içerisindeki iyonların zemin içerisine olan göçünden hemen sonra meydana gelen reaksiyon katyon değişimidir. Kireç kolonundan zemin içerisine difüze olan $\mathrm{Ca}^{+2}$ iyonları kil içerisinde mevcut olan tek değerlikli $\mathrm{Na}^{+}$iyonlarıyla yer değiştirir. $\mathrm{Ca}^{+2}$ iyonlarının yanı sıra kireçteki hidroksil $\left(\mathrm{OH}^{-}\right)$iyonları da zemin içerisine göç eder. Hidroksil iyonları zeminin alkalitesini arttırır. Yüksek alkalin koşullar silika ve alümina bileşenlerinin kil minerallerinden ayrışmasına sebep olur. Ayrışan bu bileşenler kireçten gelen $\mathrm{Ca}^{+2}$ iyonlariyla reaksiyona girerek kalsiyum silika hidrat $(\mathrm{CSH})$ ve kalsiyum alümina hidrat (CAH) gibi zeminin çimentolaşmasını sağlayan puzolanik bileşenler oluşturur. Bu puzolanik reaksiyonlar uzun bir süre içerisinde gerçekleşir ve zeminin dayanımını arttırır.

İyileşmenin gerçekleşebilmesi için her iki iyonun da zemin içerisine göç etmesi gerekir. Zeminin $\mathrm{Ca}^{+2}$ iyonlarıyla doygunluğu kil minerallerinin mevcut değişim yerlerindeki maksimum katyon değişimi için gereklidir. $\mathrm{OH}^{-}$ iyonları kalsiyum silika hidrat (CSH) ve kalsiyum alümina hidrat $(\mathrm{CAH})$ oluşturmak üzere silika ve alüminanın çözülmesi için gereken yüksek alkalin şartları $(\mathrm{pH}>12,4)$ oluşturur (Rogers ve Glendinning, 1996). Dolayısıyla kireç kolonu uygulamalarında tam bir iyileştirme $\mathrm{OH}^{-}$iyon göçünün genişliğine bağımlı kalır. Çünkü reaksiyonların gerçekleşebilmesi için yüksek pH değerleri gerekmektedir. Diğer bir ifadeyle stabilizasyon için $\mathrm{OH}^{-}$iyonları tarafindan üretilen yüksek pH şartlarına ihtiyaç vardır, ancak modifikasyon için sadece iyon değişimi yeterlidir (Rogers ve Glendinning, 1996).

$\mathrm{Ca}^{+2}$ ve $\mathrm{OH}^{-}$iyonlarının difüzyon sabitleri benzerdir ancak uzun dönemde $\mathrm{Ca}^{+2}$ iyonu $\mathrm{OH}^{-}$iyonuna göre daha hızlı ve daha geniş mesafelere göç eder (Davidson vd., 1965). Bu 
durum kirecin kil içerisinde advektif sistemde umulduğu gibi $\mathrm{Ca}(\mathrm{OH})_{2}$ iyon çifti halinde göç etmediğini gösterir. Rogers ve Glendinning (1996), $\mathrm{OH}^{-}$iyonunun $\mathrm{Ca}^{+2}$ iyonundan daha yavaş ve daha dar mesafelere göç etmesinin $\mathrm{OH}^{-}$ iyonlarının alümina silikatların yüzeyiyle olan yüksek reaktivitesinden kaynaklandığını ileri sürmüşlerdir. Başka bir ifadeyle $\mathrm{OH}^{-}$iyonlarının göç mesafesi kil minerallerinin varlığı ile sinırlanır. Ancak, suya doygun bir zeminde boşluk suyu moleküler hareketi tetikleyen termal iletkenliği arttırır ve bu olay $\mathrm{OH}^{-}$iyonlarının difüzyon hızının ve oranının önemli ölçüde artmasina neden olur (Barker vd., 2007). Beetham vd. (2014) ise $\mathrm{Ca}^{+2}$ katyon değişim sürecinin flokülasyona sebep olarak kil partiküllerinin yüzey alanını azalttığını ve bu durumun onların $\mathrm{OH}^{-}$iyonlarıyla olan etkileşimini azaltarak $\mathrm{OH}^{-}$ iyonunun daha geniş mesafelere göç etmesini sağlayacağını belirtmişlerdir. Kireç kolonu uygulamalarında iyon göçü oluşumunun genel bir gösterimi Şekil 1'de sunulmuştur.

\section{Kireç Kolonu Uygulamalarında İyon Göçü ile İlgili Önceki Çalışmalar}

Kireç kolonu uygulamalarında iyon göçü ile ilgili çalışmalara genellikle uluslararası literatürde rastlanmaktadır. Noble ve Anday (1967), mineralojisi bilinmeyen $150 \mathrm{~mm}$ çapındaki sıkıştırılmış kil örneklerinin içerisine $25 \mathrm{~mm}$ çapında kireç kolonları oluşturmuştur. Zeminörneklerinin asitleözütlenmesive akabinde EDTA (Etilen Diamin Tetra Asetik Asit) ile titre edilmesiyle serbest kalsiyum miktarı saptanarak iyon göçü mesafesi tanımlanmıştır. İyonların 44 günde $45 \mathrm{~mm}$ göç ettiği ve daha kısa mesafelerde 99 gün sonra iyon konsantrasyonlarının arttı̆̆ görülmüştür.

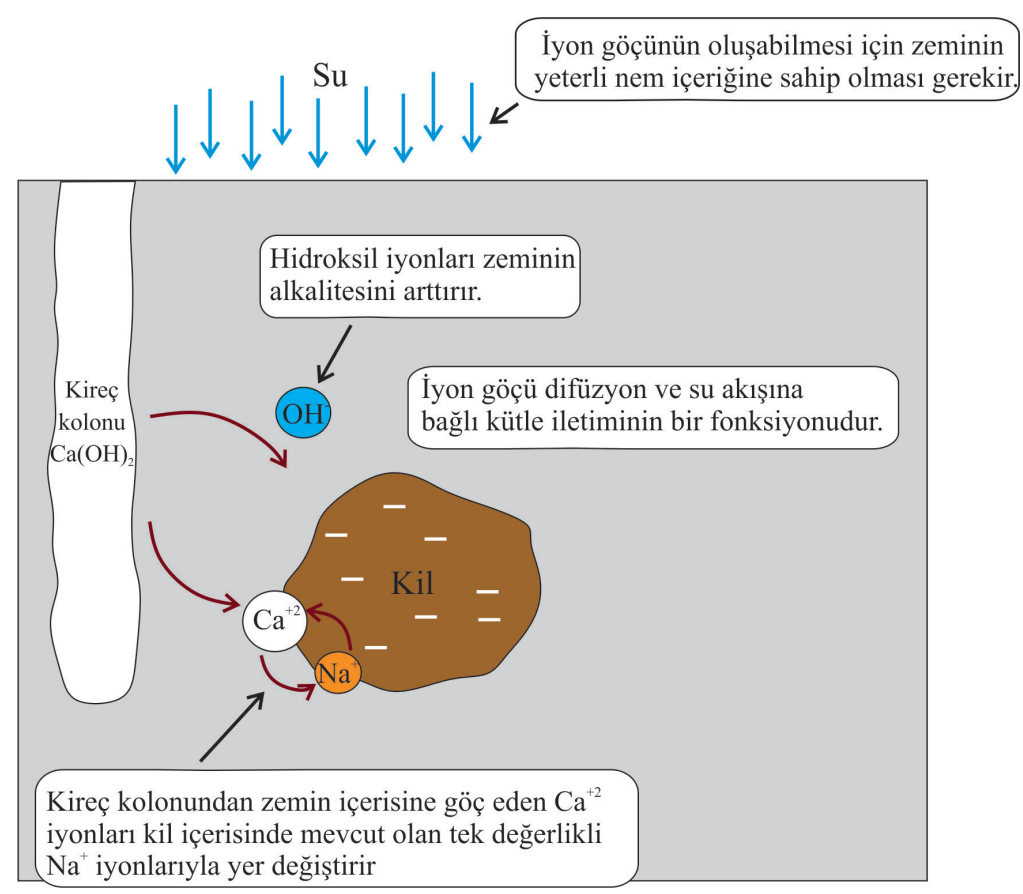

Şekil 1. Kireç kolonu uygulamalarında iyon göçü oluşumunun genel bir gösterimi.

Figure 1. A general illustration of the formation of ion migration in lime column applications. 
Katti ve Gupta (1970), vertisol toprak olarak bilinen Black Cotton Soil ( $\mathrm{LL}=\% 80, \mathrm{PL}=\% 40)$ ' de kireç göçünü bulmak için zemin içerisinde sönmemiş kireç kolonları ve kireç içerisinde zemin kolonları oluşturmuşlardır. Kirecin göç mesafesini ölçmek için tek eksenli sıkışma dayanımını ve büzülme limitini kullanmışlardır. Çalışma sonucunda, kirecin $150 \mathrm{~mm}$ çapındaki zemin örneğinin merkezine 120 gün sonra ulaştığ1 görülmüştür.

Fosh ve Kinter (1972), küçük bloklar halindeki montmorillonitik ve kaolinitik killeri iyileştirmek için yüksek kalsiyum hidratlı kireci kullanarak bir laboratuvar deneyi uygulamışlardır. Kirecin göç mesafesini bulmak amacıyla, zemindeki serbest kalsiyum miktarı EDTA titrasyonu olarak adlandırılan bir asit baz titrasyonu ile saptanmıştır. Kirecin zemin içerisindeki göç mesafesi 180 gün sonra 40 mm'den daha az olarak ölçülmüştür. Yazarlar, su hareketi ve iyon göçünün ayrı süreçler olduğunu, kil su içeriğinden bağımsız bir zemine en çok kireç katkısının en yoğun kireç çözeltisiyle sağlanabileceğini vurgulamışlardır.

Lutenegger ve Dickson (1984), orta-bat1 Amerika'da kireç kolonlarının kullanımını araştırmışlardır. Araştırmacılar, hem kilkireç reaksiyonlarında hem de iyonların difüzyon oranlarında zemin mineralojisinin önemli olduğunu vurgulamışlardır. Sadece montmorillonitik killerin kireç ile iyileştirmede uygun olduğu belirtilmiştir. Ancak, diğer killerin kireç iyileştirmesi için uygun olup olmadığını gösteren bir delil sunmamışlardır.

Rogers ve Glendinning (1994), kireç kolonu uygulamasının çalışma mekanizması konusunda bir araştırma programı yürütmüşlerdir. Araştırmacılar kireç kolonu uygulamasındaki en önemli iyileştirme sürecinin kireçteki kalsiyum iyonlarının kolon çevresindeki zemin içerisine göç etmesi ve akabindeki kil kireç reaksiyonlarının olduğunu vurgulamışlardır. Araştırma kapsamında iyileştirme mekanizmasını etkileyen her bir süreç için laboratuvar deneyleri yapılmıştır. Kireç göçünün etkisini saptamak için, $0.4 \times 0.4 \times 0.4 \mathrm{~m}$ boyutlarındaki rijit bir kutuya killi bir zemin uygun su içeriğinde sıkıştırılmış ve akabinde kutunun merkezinde $50 \mathrm{~mm}$ çapında sönmemiş bir kireç kolonu oluşturulmuştur. 8 hafta sonra kolondan itibaren çeşitli mesafelerde zemin örnekleri alınarak, örneklerin serbest kalsiyum iyon içerikleri saptanmıştır. Testler sonucunda kireç göçünün istenilen mesafede olmadığ1 görülmüştür. Kirecin göç mesafesini saptamak için, ayrıca kilin yüzeyi bir asit baz indikatörü olan fenoftaleine boyanmıştır (kireç alkalin olduğu için fenoftalein ile temas edince pembe renk alır). Fakat sadece 20 mm'lik bir göç mesafesi saptamışlardır.

Aynı araştırmacılar iyileştirme sürecini etkileyen bir diğer faktör olan nem içeriğinin iyileştirme üzerindeki etkisini araştırmak için, asit baz indikatörü ile karıştırılmış killeri farklı nem içeriklerinde, $32 \mathrm{~mm}$ çapındaki perpeks tüplere doldurmuşlardır. Her tüpün merkezine 6 mm çapında sönmemiş kireç kolonu oluşturulmuş ve kirecin renk değişiminden faydalanarak iyonların tüpün ucuna ulaşması için gereken zaman ölçülmüş ve kaydedilmiştir. Çalışma sonucunda, nem içeriğindeki artışın iyon göçünü artırdığı sonucuna varılmıştır.

Rogers ve Glendinning (1996), kolon uygulamasında kireç göçü mesafesi ile ilgili literatürü gözden geçirmişler ve kireç göçü mekanizmasını tanımlamak için sönmemiş kireç kolonlarını kullanarak bir araştırma yapmışlardır. Çalışma sonucunda, örselenmemiş doğal kilde difüzyon süreciyle meydana gelen $\mathrm{OH}^{-}$iyon göçünün yaklaşık 20-30 mm ile sınırlı olduğu görülmüştür. Ancak kil kütlesindeki dehidrasyon 
çatlağı ya da diğer süreksizlikler aracılığıyla artan hidrolik iletkenliğin daha büyük mesafelerde göçe yol açtığ 1 vurgulanmıştır. Ayrıca, $\mathrm{Ca}^{+2}$ iyon göçünün 10 yıl içerisinde $1 \mathrm{~m}$ 'den daha büyük mesafelerde olabileceği tahmin edilmiştir.

Barker vd. (2006), bir dizi laboratuvar deneyi aracılığılyla, Londra kilinde kireç kolonundan olan iyon göçünün sebep olduğu fiziksel ve kimyasal olayları incelemişlerdir. Çalışmada, iyon göçünün üç etmenin (kimyasal, elektriksel ve hidrolik eğim) etkisi altında meydana geldiği görülmüştür.

Toksöz ve Y1lmaz (2020), şişen zeminlerin kireç kolonu ile iyileştirilmesinde zemin içerisindeki şişen kil içeriğinin iyon göçü üzerindeki etkisini araştırmışlardır. Araştırmacılar amaca yönelik olarak ağırlıkça $\% 0, \% 20, \% 40, \% 60, \% 80$ ve $\% 100$ oranlarında bentonit içeren zemin örnekleri hazırlamış olup her zemin örneği için laboratuvarda modeller oluşturmuşlardır. Modellerde oluşan $\mathrm{Ca}^{+2}$ iyon göçü mesafesini belirlemek amacıyla kolondan itibaren belirli mesafelerde alınan numunelerin $\mathrm{Ca}^{+2}$ iyon içerikleri EDTA analizi ile saptanmıştır. $\mathrm{OH}^{-}$iyon göçü mesafesini belirlemek için ise bir asit baz indikatörü olan fenoftalein kullanılmıştır. 2 aylık kür süresi sonunda hem $\mathrm{Ca}^{+2}$ hem $\mathrm{OH}^{-}$ iyon göçü mesafesinin zeminlerdeki bentonit oran1 arttıkça azaldığ1 görülmüştür (Şekil 2). Araştırmacılar $\mathrm{Ca}^{+2}$ iyon göçü mesafesinin şişen kil oranının artmasıyla azalmasının sebebinin katyon değişimi reaksiyonları olabileceğini belirtmişlerdir. Killi bir zemine kireç eklendiği zaman öncelikle katyon değişimi reaksiyonları gerçekleşir ve kireç içerisindeki $\mathrm{Ca}^{+2}$ iyonları kilin içerisindeki $\mathrm{Na}^{+}$iyonları ile yer değiştirir. $\mathrm{Bu}$ iyon değişimi reaksiyonları $\mathrm{Ca}^{+2}$ iyonunun zemin içerisindeki göçünü yavaşlatabilir. $\mathrm{OH}^{-}$iyon göçü mesafesinin şişen kil oranının artmasıyla azalmasının sebebinin ise $\mathrm{OH}^{-}$iyonlarının alümina silikatların yüzeyiyle olan yüksek reaktivitesi olduğunu ifade etmişlerdir. Montmorillonit kil minerali oldukça büyük bir yüzey alanına sahiptir. Dolayısıyla, $\% 100$ bentonit içeren zemin numunesinde $\mathrm{OH}^{-}$iyonunun kil mineralleriyle olan etkileşimi artmakta ve bu durum iyonun hareketini kısıtlamaktadır. $\% 0$ bentonit içeren zemin numunesine doğru hem montmorillonit miktarı hem de kil mineral içeriği azalmaktadır. Dolayısıyla $\mathrm{OH}^{-}$iyonunun hareketi daha kolay olmakta ve iyon daha büyük mesafelere kadar göç edebilmektedir. $\mathrm{OH}^{-}$ve $\mathrm{Ca}^{+2}$ iyonlarının göçleri kıyaslandığında ise $\mathrm{Ca}^{+2}$ iyonunun $\mathrm{OH}^{-}$ iyonuna göre daha büyük mesafelere kadar göç ettiği gözlenmiştir. $\mathrm{Bu}$ durumun ise yine $\mathrm{OH}^{-}$ iyonunun silikatların yüzeyiyle olan yüksek reaktivitesinden kaynaklandığı belirtilmiştir. $\mathrm{OH}^{-}$iyonunun göçü bütün kil mineral içeriğiyle kısıtlanmakta iken $\mathrm{Ca}^{+2}$ iyonunun göçü Namontmorillonit içeriği ile kısıtlanmaktadır. Dolayısıyla $\mathrm{Ca}^{+2}$ iyonu $\mathrm{OH}^{-}$iyonuna göre daha büyük mesafelere kadar göç edebilmektedir.

Konu ile ilgili yapılan önceki çalışmalardan görüleceği üzere kireç kolonu uygulamalarında oluşan iyon göçü kısa mesafelerle sınırlıdır. Bunun başlica nedeni zeminin heterojen bir ortam olması ve iyon göçünün pek çok faktörün etkisi altında bulunmasıdır. Kireçteki iyonların zemin içerisine göç etmesini etkileyen bu faktörlerden bazıları bir sonraki bölümde açıklanmıştır.

\section{Kireç Kolonu Uygulamalarında İyon Göçünü Etkileyen Faktörler}

Kireçteki iyonların kolonu çevreleyen zemin içerisine göç etmesini etkileyen pek çok faktör söz konusudur. Bu faktörler zeminin su içeriği, gözenekliliği, geçirimliliği, zemin içerisindeki kayma düzlemleri, kil mineralojisi, osmotik basınç, zeminin emme kuvveti, kür zamanı, kür sıcaklığı olarak sayılabilir (Mitchell ve Hooper, 1961; Rogers ve Glendinning, 1994). 
Derleme / Review Paper

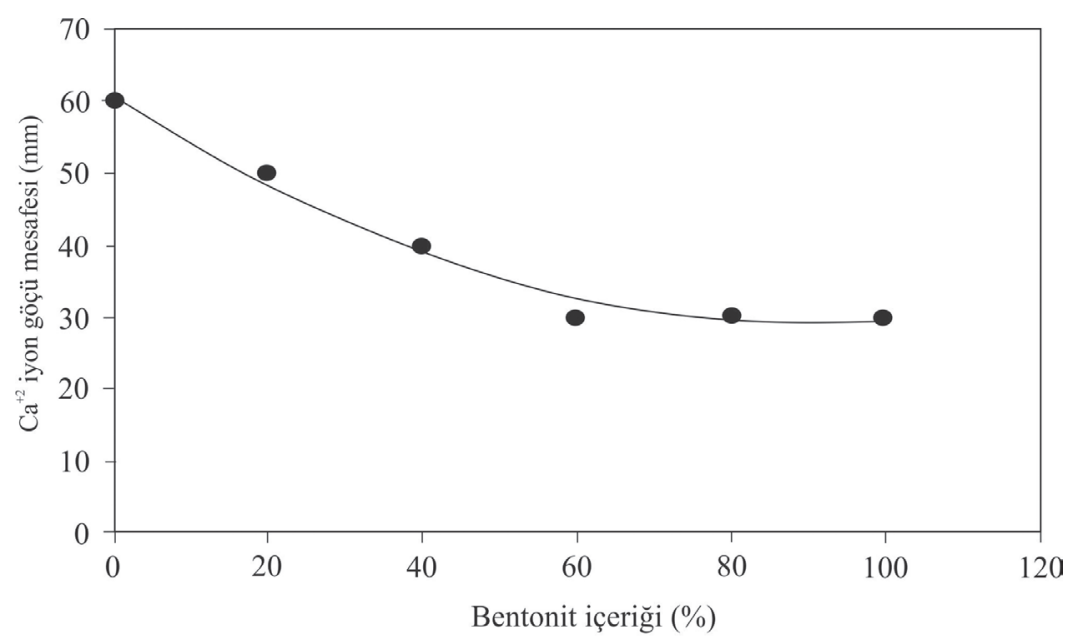

(a)

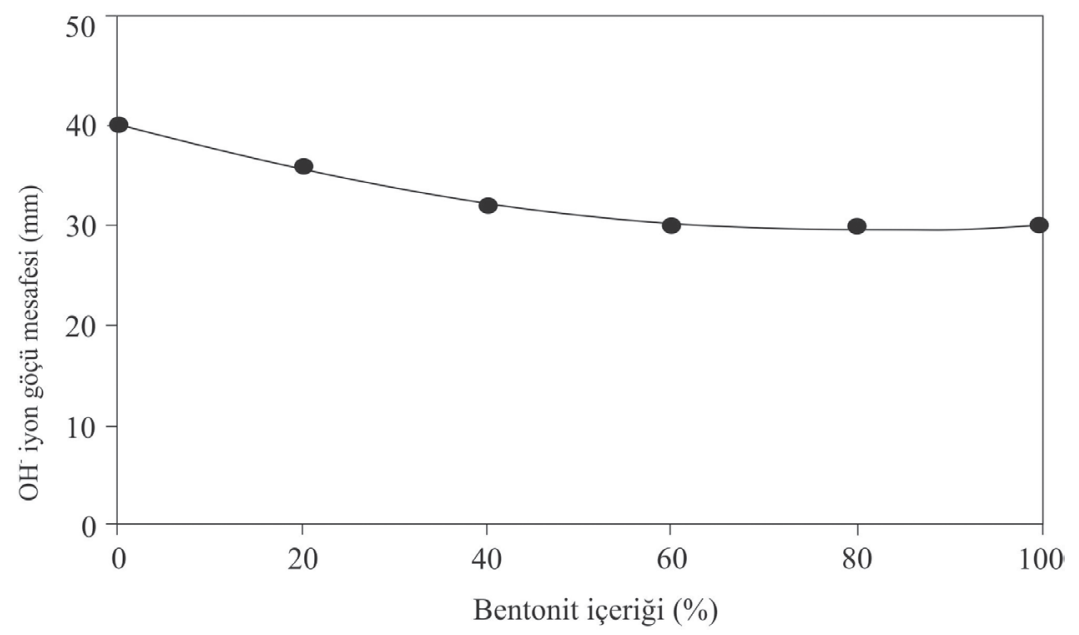

(b)

Şekil 2. $\mathrm{Ca}^{+2}$ ve $\mathrm{OH}^{-}$iyon göçü mesafeleri ile zemin içerisindeki bentonit oranı arasındaki ilişki (Toksöz ve Yılmaz, 2020 ' den değiştirilmiş).

Figure 2. The relationship between the $\mathrm{Ca}^{+2}$ and $\mathrm{OH}^{-}$ion migration distances and the bentonite ratio in the soil (modified from Toksöz and Yllmaz, 2020).

\section{Zeminin su içeriği}

Bazı araştırmacılar zeminin su içeriğindeki artışın iyon göçünü arttırdığını savunurken (Ruenkrairergsa ve Pimsarn, 1982; Lutenegger ve Dickson, 1984; Shanker vd., 1989; Rogers ve Glendinning, 1996) diğer araştırmacılar su içeriğindeki artışın iyon göçü üzerinde bir etkisi olmadığını savunmuşlardır (Katti ve Gupta, 1970;
Fosh ve Kinter, 1972). Katti ve Gupta (1970), yaptıkları çalışmada iyon göçünün düşük su içerikleri ve yüksek yoğunluklar ile sağlandığını ve kapileritenin göçü kontrol eden faktör olduğunu gözlemlemişlerdir. Ancak Rogers ve Glendinning (1996), yaptıkları deneylerde su içeriğindeki artışın iyon göçünü arttırdığını bulmuşlardır (Şekil 3). Pek çok araştırmacı zemin 
Toksöz Hozatlığlu, Yılmaz

içerisinde gözlenebilir bir su hareketi olmasa bile suyun varlığını iyon göçü için gerekli görmüştür (Barker vd., 2007). Zeminin su içeriğinin iyon göçü üzerindeki etkisi hakkında literatürde kesin bir görüş birliği olmamasına rağmen gözlemlerin çoğu su içeriğindeki artışın iyon göçünü arttırdığ1 ve bu yüzden kireç kolonlarının yağmurlu mevsimlerden önce inşa edilmesi gerektiği yönündedir.

\section{Hidrolik gradyan}

Hidrolik gradyan ve iyon göçü arasındaki ilişkiyi araştıran çok az çalışma mevcuttur. Farklı arazi gözlemlerinden iyon göçünün yeraltı suyu tablasının altındaki seviyelerde arttı̆̆ anlaşılmaktadır (Handy ve Williams, 1967). Ancak bu durumun yer altı suyunun hareketinden mi yoksa zeminin doygun olmasindan $\mathrm{m}$ kaynaklandığı hakkında kesin bir sonuca varılamamıştır.

Lutennegger ve Dickson (1984) tarafindan kireç kolonu tekniği ile ilgili yapılan bir derlemede $\mathrm{Ca}^{+2}$ iyonlarının göçünün zeminde suyun varlığı ile sağlandığı vurgulanmıştır. Araştırmacılar Katti ve Gupta (1970)' nın en büyük iyon göçünün suyun akış yönünde olduğunu gözlemlediklerini rapor etmişlerdir. Dolayısıyla kireçteki iyonların tercihen suyun akış yönünde göç ettikleri oldukça olasıdır.

\section{Geçirimlilik}

Brandl (1981), kireç kolonu uygulaması için en uygun zeminlerin gevşek paketlenmiş ve düşük plastisiteli zeminler olduğunu ve bunun nedeninin bu zeminlerin yüksek geçirimliliğe sahip olduklarından kaynaklandığını vurgulamıştır. Araştırmacı yüksek geçirimliliğin kirecin daha fazla difüzyonunu engelleyen çabuk çimentolaşma reaksiyonlarının önüne geçtiğini belirtmiştir. Ayrıca, zeminin geçirimliliği hidrolik iletkenliği arttıracağından iyon göçünü de arttıracaktır (Rogers ve Glendinning, 1996).

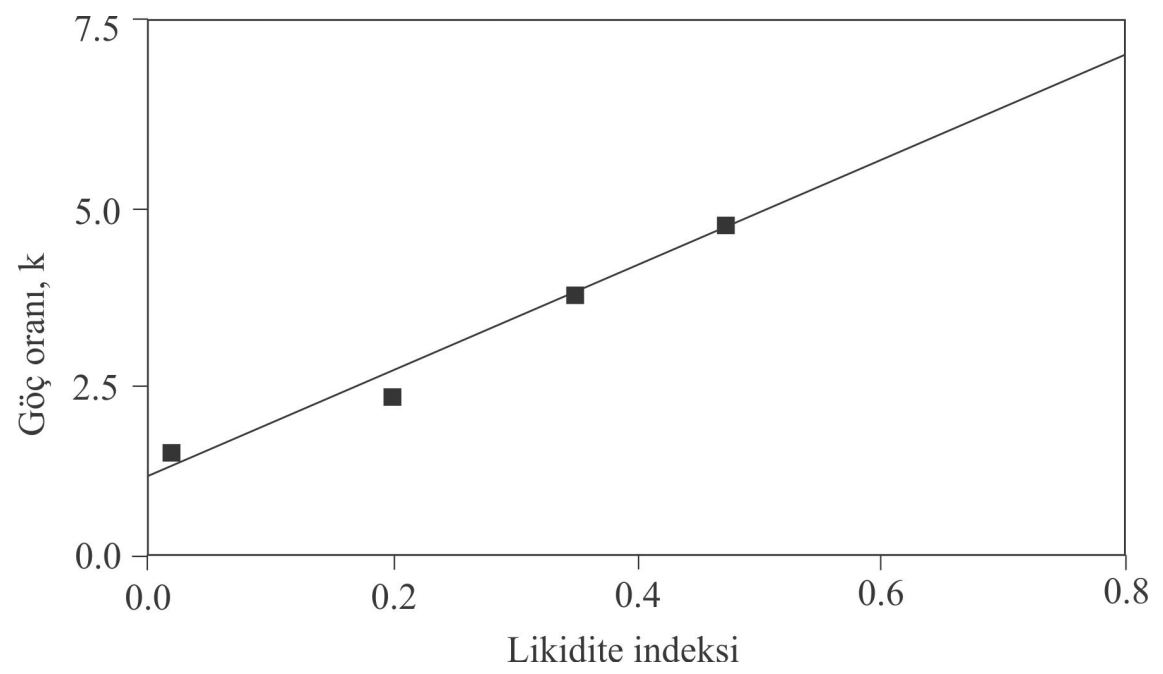

Şekil 3. Su içeriği (likidite indeksi) ve göç oranı arasındaki ilişki (Rogers ve Glendinning, 1996'dan değiştirilmiş). Figure 3. Relationship between water content (liquidity index) and migration rate (modified from Rogers ve Glendinning, 1996). 


\section{Gözeneklilik ve kayma düzlemleri}

Rogers ve Glendinning (1996), farklı kil türleri üzerinde yapmış olduğu çalışmada yüksek gözenekliliğe sahip olan zemin türünde daha fazla iyon göçü mesafeleri saptamışlardır. Bunun nedeninin artan gözenekliliğe bağlı olarak su içeriğindeki artış olduğunu vurgulamışlardır. Araştırmacılar ayrıca, iyon göçünün tercihen zemin içerisindeki en az dayanımlı yollar, diğer bir deyişle kayma düzlemleri boyunca olacağını vurgulamışlardır. Bunun nedeni yine kayma düzlemlerinin geçirimliliği arttırmasıdır.

\section{Mineraloji}

Killi zeminler geniş bir mineralojik bileşim aralığına sahiptirler. Bu zeminler farklı oranlarda kil türleri içerebilirler. $\mathrm{Bu}$ kil mineralleri başlıca kaolinit, illit, karışık katmanlı killer ve montmorillonittir. Kil olmayan minerallerden ise kuvars, kalsit ve organik madde içerebilirler. Belirli kil minerallerinin küçük bir miktarı killi bir zeminin fiziksel özellikleri üzerinde büyük bir etkiye sahip olabilir (Bell, 1996).

Kireç stabilizasyonu ile ilgili bugüne kadar yapılan araştırmalara göre zeminin mineralojisi kireç-kil-su reaksiyonunda çok önemli bir rol oynamaktadır. Fosh ve Kinter (1972) montmorillonit kil mineralinin baskin olarak bulunduğu killi balçık (killi kum) bir zemindeki kalsiyum iyonu göç mesafesinin kaolin kil mineralinin baskın olduğu killi bir zemindekinden daha fazla olduğunu gözlemlemişlerdir. Bunun nedeninin killi balçık zeminin daha büyük partikül boyutlarına sahip olduğundan kaynaklandığını ileri sürmüşlerdir. Ancak 80 günden az bir kür süresinde kireç kolonundan itibaren 8-14 mm'lik bir bölgede kaolinitik kilin daha yüksek seviyede kalsiyum içeriğine sahip olduğu gözlemlenmiştir. Bunun nedeninin ise kesin olmadığını belirtmişlerdir.
Lutennegger ve Dickson (1984) zeminin mineralojisinin hem iyileştirme reaksiyonlarının gerçekleşmesinde hem de iyonların difüzyon oranında etkili olduğunu vurgulamışlardır. Araştırmacılar sadece montmorillonitik zeminlerin kireç kolonu tekniğiyle iyileştirmek için uygun olduklarını savunmuşlardır. Ancak diğer zeminlerin kireç kolonuyla iyileştirilemeyeceğini gösteren bir delil sunmamışlardır.

Diamond ve Kinter (1966), montmorillonit ve kaolinit kil minerallerinin $\mathrm{Ca}(\mathrm{OH})_{2}$ adsorpsiyonunu incelemişlerdir. Adsorpsiyonun kilin dış yüzeyleriyle sınırlı olduğu belirtilmiştir. Araştırmacılar elde ettikleri verilerden yaptıkları gözlemden montmorillonitin tüm dış yüzeyinin $\mathrm{Ca}(\mathrm{OH})_{2}$ ile kaplandığını kaolinitin ise sadece yarısının $\mathrm{Ca}(\mathrm{OH})_{2}$ ile diğer yarısının su ile kaplandığı sonucunu çıkarmışlardır. Bunun nedeninin iki kil mineralinin düzlemsel yüzeylerinin bileşimindeki farklılık olabileceği vurgulanmıştır. Montmorillonitin düzlemsel yüzeyleri silika tabakasına bağlı oksijenlerden oluşur. Kaolinitin ise sadece yarısı bu tiptir, diğer yarısı alümina tabakasına bağlı hidroksil iyonlarından oluşur. Şekil 4'te montmorillonit ve kaolinit killerinde gözlenen adsorpsiyon eğrileri sunulmuştur.

\section{Kür zamanı ve kür sıcaklı̆̆}

Barker vd. (2007) iyon göçünün başlangıç su içeriğine, kür zamanına, zemin mineralojisine ve kimyasal, elektriksel, hidrolik ve termal gradyanların varlığına bağlı olduğunu belirtmişlerdir. Kireç içerisindeki iyonların kolonu çevreleyen zemin içerisine göç etmesi zaman içerisinde gerçekleşir. İyonların zemin içerisinde belli bir mesafe boyunca göç etmeleri için gerekli zaman tahmin edilebilseydi en uygun 
Toksöz Hozatlıoğlu, Yılmaz

kür süresine karar verilebilirdi. Davidson vd. (1965) tarafindan önerilen eşitliğe göre difüzyon mesafesi zamanın karaköküyle orantılıdır.

$\mathrm{L}=\mathrm{k} \cdot \mathrm{t}^{0.5}$

Burada;

$\mathrm{L}=$ difüzyon mesafesi,

$\mathrm{t}=$ zaman,

$\mathrm{k}=$ kil türüne bağlı katsayı (kil içeriği, kil mineralojisi, yoğunluk, adsorbe edilen katyonlar ve sicaklığın bir fonksiyonudur).

Davidson vd. (1965) bu eşitliğin kil-kireç reaksiyon oranının kireç göçü oranından büyük olduğu durumlarda geçerli olduğunu ve bu yüzden su hareketinin çok fazla olduğu durumlarda uygulanmaması gerektiğini belirtmişlerdir.

Zemin içerisindeki iyonların göçünü etkileyen faktörlerden biri de sıcaklıktır. Sıcaklık iyon göçünü sağlayan elektriksel, hidrolik ve termal gradyanların varlığına sebep olan etmenler arasındadır (Barker vd., 2007). Sıcaklığın artması ile birlikte iyonların kinetik enerjisi artmakta ve difüzyon hızlanmaktadır.

Diamond ve Kinter (1966), sicaklığın montmorillonitin $\mathrm{Ca}(\mathrm{OH})_{2}{ }^{\prime} \mathrm{i}$ adsorblaması üzerindeki etkisini araştırmak için $5^{\circ} \mathrm{C}, 25^{\circ} \mathrm{C}$ ve $50{ }^{\circ} \mathrm{C}$ sicaklıklardaki adsorpsiyon oranlarını karşılaştırmışlardır. Deney sonucunda, $5{ }^{\circ} \mathrm{C}$ ve $25^{\circ} \mathrm{C}$ sicakliklardaki $\mathrm{Ca}(\mathrm{OH})_{2}$ adsorpsiyonunun yaklaşık eşit oranlarda olduğu gözlenirken sıcaklığın $50{ }^{\circ} \mathrm{C}$ ' ye çıkması ile adsorpsiyon oranının önemli bir şekilde arttığ 1 görülmüştür (Şekil 5). Yazarlar, bunun sebebini $\mathrm{Ca}(\mathrm{OH})_{2}{ }^{\prime}$ in çözünebilirliğinin sicaklıkla birlikte artmasına bağlamışlardır. Ayrıca, $\mathrm{Ca}(\mathrm{OH})_{2}$ adsorpsiyonunun yaklaşık oda sıcaklığında fiziksel olabileceği, ancak daha yüksek sıcaklıklarda kemisorpsiyonun etkin olabileceği belirtilmiştir.

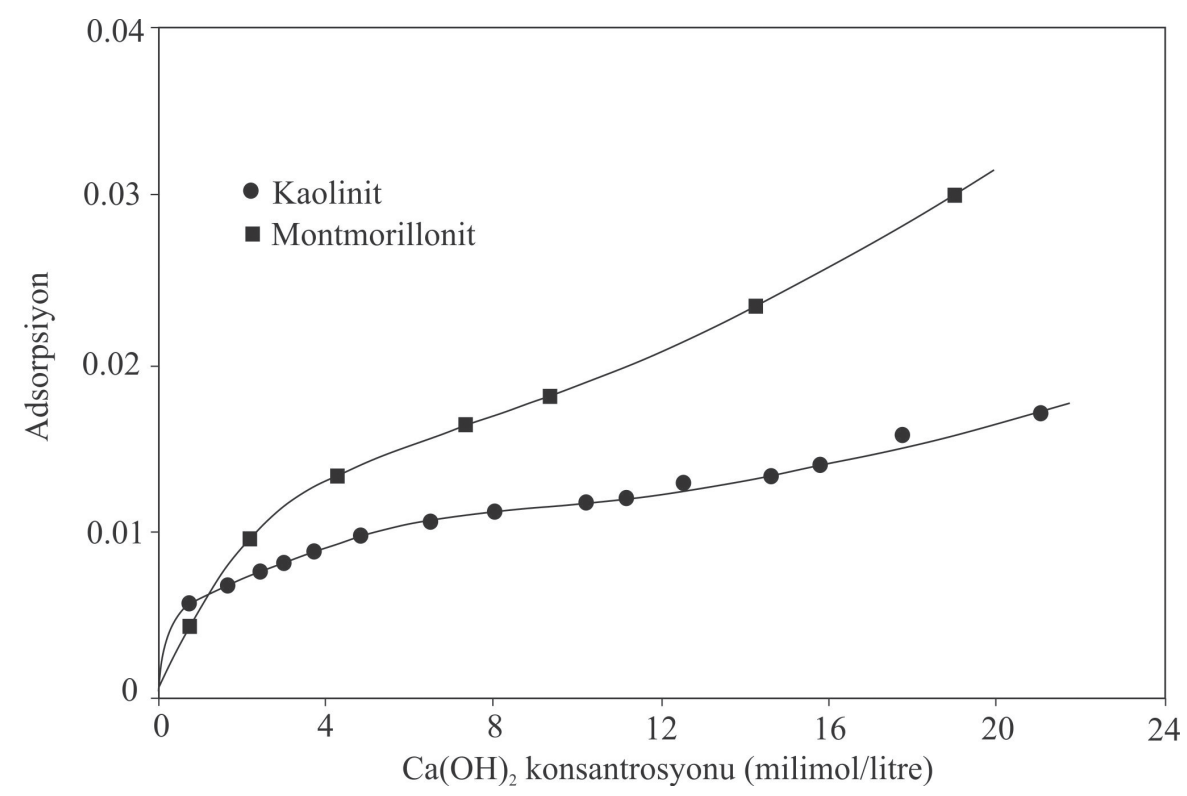

Şekil 4. $25^{\circ} \mathrm{C}$ sıcaklıkta montmorillonit ve kaolinit killerinde gözlenen $\mathrm{Ca}(\mathrm{OH})_{2}$ adsorpsiyon eğrileri (Diamond ve Kinter 1966' den değiştirilmiş).

Figure 4. The $\mathrm{Ca}(\mathrm{OH})$, adsorption curves observed in montmorillonite and kaolinite clays at $25^{\circ} \mathrm{C}$ (modified from Diamond and Kinter, 1996). 


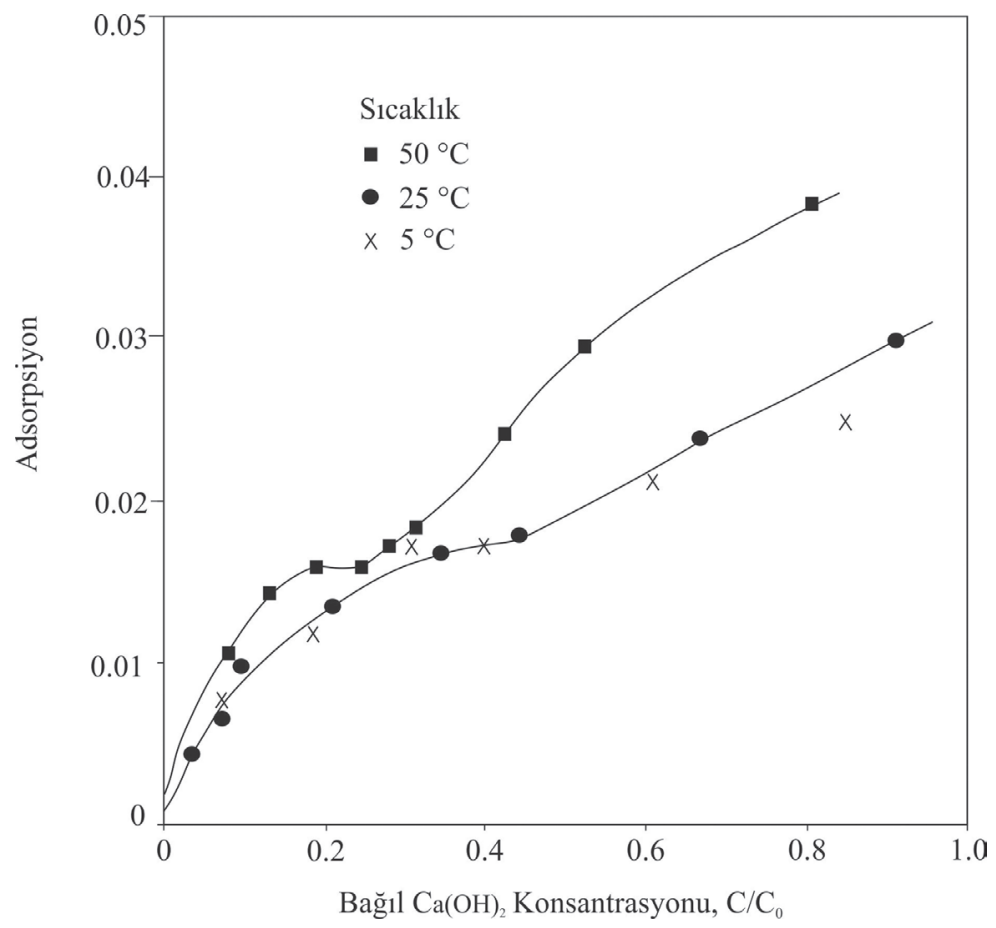

Şekil $5.5^{\circ}, 25^{\circ}$ ve $50^{\circ} \mathrm{C}$ sicaklıklarda montmorillonit kilinde gözlenen $\mathrm{Ca}(\mathrm{OH})_{2}$ adsorpsiyon eğrileri, (Diamond ve Kinter, $1966^{\prime}$ dan değiştirilmiş).

Figure 5. The $\mathrm{Ca}(\mathrm{OH})_{2}$ adsorption curves observed in montmorillonite and kaolinite clays at $5^{\circ}, 25^{\circ}$ and $50{ }^{\circ} \mathrm{C}$ (modified from Diamond and Kinter, 1966).

\section{SONUÇLAR}

Şişen zeminlerin kireç kolonu tekniği ile iyileştirilmesi ile ilgili olarak ulusal ve uluslararası literatürde pek çok çalışma mevcuttur. $\mathrm{Bu}$ çalışmalarda kireç kolonu tekniğinin iyileştirme mekanizmasının kireçteki iyonların kolonu çevreleyen zemin içerisine göç etmesiyle oluşan fizikokimyasal reaksiyonlara dayandığ 1 belirtilmiştir. Ancak oluşan bu iyon göçünün mekanizmasından çok az sayıda çalışmada bahsedilmiştir. Söz konusu çalışmalar ise çoğunlukla uluslararası literatürde olup ulusal literatürde konu ile ilgili bir çalışma neredeyse yok gibidir. Dolayısıyla mevcut çalışma ulusal literatürdeki bu eksikliği gidermek ve kireç kolonu uygulamalarında iyon göçü mekanizmasının daha iyi anlaşılması amacıyla hazırlanmıştır.

Konu ile ilgili çalışmalar göstermektedir ki zeminlerde oluşan iyon göçü sıvı bir çözeltide oluşan iyon göçünden çok daha karmaşıktır. Bunun nedeni zemin içerisindeki göç yollarının lineer olmayışı, zeminin heterojen bir yapıya sahip olması ve iyon göçünü etkileyen pek çok faktörün bulunmasıdır. Dolayısıyla literatürde iyon göçünü açıklayan tek ve kesin bir mekanizma bulunmamaktadır. Ancak yapılan çalışmalardan yola çıkılarak kireç içerisindeki iyonların zemin içerisine olan göçünün genel olarak iyon difüzyonu ve su akışına bağlı kütle iletiminin bir fonksiyonu olduğu söylenebilir. 
Toksöz Hozatlıoğlu, Yılmaz

Yine yapılan çalışmalar göstermektedir ki $\mathrm{Ca}^{+2}$ iyonu $\mathrm{OH}^{-}$iyonuna göre daha hizlı ve geniş mesafelere kadar göç edebilmektedir. Araştırmacılar bunun nedeninin $\mathrm{OH}^{-}$ iyonlarının alümina silikatların yüzeyiyle olan yüksek reaktivitesinden kaynaklandığını ileri sürmüşlerdir.

Zeminin su içeriği, gözenekliliği, geçirimliliği, zemin içerisindeki kayma düzlemleri, kil mineralojisi, osmotik basınç, zeminin emme kuvveti, kür zamanı ve sıcaklığ1 kireçteki iyonların kolonu çevreleyen zemin içerisine göç etmesini etkileyen faktörler arasındadır. Kireç kolonu uygulamalarının söz konusu faktörler dikkate alınarak yapılması kolon performansı açısından önemlidir.

Kireç kolonu uygulamalarında iyon göçü mekanizmasının anlaşılması laboratuvar ve arazi uygulamalarının daha sağlıklı bir şekilde yapılmasına olanak sağlayacaktır. Ayrıca iyon göçü mesafelerinin ön laboratuvar çalışmalarında saptanması daha sonra oluşturulacak büyük ölçekli modellerde kolonlar arası bırakılacak mesafeye karar vermede ya da kür süresin belirlenmesinde yardımcı olacaktır.

\section{KAYNAKLAR}

Adar, E., 2013. Katı Atık Düzenli Depo Sahalarında Alternatif Taban Sistemlerinden Sizıntı Suyu Kirleticilerinin Geçişinin İncelenmesi. Yüksek Lisans Tezi, Yıldız Teknik Üniversitesi, Fen Bilimleri Enstitüsü, İstanbul.

Barker, J.E., Rogers, C.D.F., Boardman, D.I., 2006. Physio-chemical changes in clay caused by ion migration from lime piles. Journal of Materials in Civil Engineering, 18, 182-189.

Barker, J.E., Rogers, C.D.F., Boardman, D.I., 2007. Ion Migration Associated with Lime Piles: A Review. Proceedings of the ICE - Ground Improvement, 11(2):87-98.

Beetham, P., Dijkstra, T.A., Dixon, N., 2014. Lime Diffusion and Implications for Lime
Stabilization Practice. Compendium of papers from the Transportation Research Board 93rd annual meeting, Washington DC. TRB, USA.

Bell, F.G., 1996. Lime stabilization of clay minerals and soils. Engineering Geology, 42, 223-237.

Brandl, H., 1981. Stabilization of slippage-prone slopes by lime piles. Proceedings $8^{\text {th }}$ International Conference on Soil Mechanics and Foundation Engineering, Moscow, USSR, pp 300-301.

Davidson, L.K., Demeril, T., Handy, R.L., 1965. Soil pulverization and lime migration in soil lime stabilization. Highways Research Board Record, 92, 103-126.

Diamond, S., Kinter, E.B., 1966. Adsorption of calcium hydroxide by montmorillonite and kaolinite. Journal of Colloid and İnterface Science, 22(3), 240-249.

Edil, T.B., 2003. A review of aqueous-phase VOC transport in modern landfill liners. Waste Management, 23, 561-571.

Fohs, D.G., Kinter, C.B., 1972. Migration of lime in compacted soil. Public Roads, 37 (1), 1-8.

Handy, R.L., Williams, N.W., 1967. Chemical stabilization of an active landslide. Civil Engineering, 37 (8),62-65.

Jungnickel C, Smith D., Fityus S., 2004. Coupled multi-ion electrodiffusion analysis for clay soils. Canadian Geotechnical Journal, 41(2), 287-298.

Katti, R. K., Gupta, A. K., 1970. Studies on the diffusion of lime in expansive soil. Proceedings 2nd S E Asian Conference on Soil Engineering, 611-619.

Lutenegger, A.J., Dickson, J.R., 1984. Experiences with drilled lime stabilisation in the mid-west USA. Proceedings of the Fourth International Symposium on Landslides, 289-293.

Mitchell, J.K., Hooper, D.R., 1961. Influence of time between mixing and compaction on properties of lime stabilized expansive clay. Highway Research Board Bulletin, 304, 14-31. 
Mitchell, J.K., Soga, K., 2005. Fundamentals of Soil Behavior. 3rd Edition, John Wiley and Sons, Hoboken, 592 pages.

Noble, D.F., Anday, M.C., 1967. Migration of lime deposited in drill holes. Virginia Highway Research Council Publication.

Rogers, C.D.F., Glendining, S., 1994. Deep Slope Stabilisation Using Lime. Transportation Research Record 1440, Transportation Research Board, National Research Council, Washington D.C., USA, p.63-70.

Rogers, C.D.F., Glendinning, S., 1996. The role of lime migration in lime pile stabilisation of slopes. Quaterly Journal of Engineering Geology, 29 (4), 276-284.

Ruenkrairergsa, T., Pimsarn, T., 1982. Deep hole lime stabilisation for unstable clay shale embankment. Proceedings of the 7th SE Asia Geotechnics Conference, Hong Kong, 22-26th November, 1982, p.631-645.
Shanker, N., Babu N., Maruti, G., 1989. Use of lime soil piles for in-situ stabilisation of Black Cotton soils. Indian Geotechnical Conference, Visakhapatnam, 1, 149-153.

Snethen, D.R., 1979. Technical Guidelines for Expansive Soils in Highway Subgrades. Department of Trans-poration, U.S.A., Final Report No. FHWA-RD-79-51.

Öztaş, T., 1997. Topraklarda Difuzyon ve Dispersiyon Arasındaki İlişki. Atatürk Üniv. Ziraat Fak. Dergisi, 28 (1), 153-160.

Toksoz, D., Y1lmaz, I., 2020. Influence of swelling clay content on ion migration and column performance in lime column treated soils. Geotechnical and Geological Engineering, 38(1), 813-832. 